\title{
NEGYEDIK IPARI VAGY HARMADIK INFORMATIKAI FORRADALOM? AZ INFORMÁCIÓ SOK EZER ÉVES HATALMA
}

\section{FOURTH INDUSTRIAL OR THIRD INFORMATION REVOLUTION? THE POWER OF INFORMATION FOR TENS OF MILLENNIA}

\author{
Bojár Gábor \\ alapító, elnök, Graphisoft SE Európai Részvénytársaság \\ gboja@@graphisoft.hu
}

ÖSSZEFOGLALÁS

Az informatikai forradalom jelentőségének érzékeltetésére széles körben elterjedt a „negyedik ipari forradalom" elnevezés. Szerintünk ez a megnevezés félreérti és alábecsüli a napjainkban zajló technológiai forradalom szerepét és jelentőségét életünkben. Amikor felbecsülni próbáljuk az IT-forradalom hatását életünkre, munkánkra, sőt az emberi faj egészének jövőjére, akkor ezt nem az ipari forradalmakkal, hanem az emberiség sorsát ezeknél sokkal alapvetőbben befolyásoló két korábbi „informatikai forradalommal”, a beszéd (információcsere) majd az írás (az információ tárolása) megalkotásával kell párhuzamba állítani.

\section{ABSTRACT}

The "Fourth Industrial Revolution" expression is widely used to emphasize the importance of the Information Technology Revolution. We believe, however, that this expression is a misunderstanding and understatement of the role and importance of this technology revolution in our lives. If we are trying to gauge its effects on the way we are living, working and even on the future of the entire human race, then it is much more appropriate to compare the current IT revolution to two earlier "information revolutions" that fundamentally influenced the fate of humanity, to the invention of speech (exchanging information) and to the invention of writing (preserving information).

Kulcsszavak: Klaus Schwab, negyedik ipari forradalom, Ipar 4.0, informatikai forradalom, ordinateur

Keywords: Klaus Schwab, fourth industrial revolution, Industry 4.0, information revolution, IT revolution, ordinateur 
A 2016-os Világgazdasági Fórumon hangzott el először a fórum alapítója, Klaus Schwab előadásában, majd könyvének címeként a Fourth Industrial Revolution, azaz a negyedik ipari forradalom kifejezés (Schwab, 2016). A könyv részletesen ismerteti a napjainkban zajló technológiai forradalom lenyügözően csodálatos alkotásait, azoknak életünkre, munkánkra, társadalmunkra gyakorolt számtalan, részben már ma is érezhető, részben várható hatását. Ezek nagy részével egyetértek, kizárólag a Schwab nyomán széles körben elterjedt „,negyedik ipari forradalom" elnevezéssel szeretnék vitatkozni, mert úgy érzem, az informatika mai forradalmát nem az ipari forradalmakkal, hanem az emberiség sorsát ezeknél sokkal alapvetőbben befolyásoló két korábbi „informatikai forradalommal” indokoltabb párhuzamba állítani.

Ez a gondolat elsősorban korábbi szoftvervállalkozásom piaci tapasztalatán alapul, az antropológiai, genetikai, történelmi és nyelvészeti hivatkozások pedig - a tudományos alaposság igénye nélkül - két népszerü munkára támaszkodnak, Jared Diamond $A$ harmadik csimpánz felemelkedése és bukása, továbbá Yuval Noah Harari Sapiens címü könyvére.

\section{EGY PIACI KUDARC NYOMÁN SZÜLETETT KONCEPCIÓ}

Volt cégem, a Graphisoft, háromdimenziós építészeti tervező szoftverét eleinte csak a tervek látványos bemutatására kínálta, de rövidesen azt kellett tapasztalnunk, hogy a pontos müszaki rajzok elkészítését segítő kétdimenziós „CAD” (számítógéppel segített tervezö/rajzoló) szoftverek értékesebbek voltak a piacon. A rajzolás fáradságos munkáját kiváltó kétdimenziós program gyakorlati haszna sokkal több volt, mint a háromdimenziós látványterveké. Erre a kihívásra válaszként született a „virtuális épület” koncepció, amely később BIM, azaz Building Information Modelling, tehát „épületinformáció-modellezés” néven általánosan elfogadottá vált, és kiszorította a ma már meghaladottnak tekintett CAD-et az építészeti tervezésben. A BIM lényege, hogy a háromdimenziós épületmodellt nemcsak látványtervek készítésére használjuk, hanem az egy részletes adatbázis az épületről, ebből származnak a kiviteli tervek, anyagkimutatások, és az épületről szóló egyéb dokumentumok. A rajzok így a tervezés és kivitelezés során mindvégig konzisztensek maradnak egymással, hiszen minden módosítást a modellen végzünk, így az ebböl származtatott rajzok és egyéb dokumentumok pontosan követik a menet közbeni változásokat, elkerülve azokat a hibákat, inkonzisztenciákát, amelyek a hagyományos kétdimenziós tervek gyakori módosítása során szinte mindig előfordulnak.

Ezzel a megoldással sikerült gyökeresen átalakítani az építész szerepét is az építőiparon belül. A tervező nem elsősorban a rajzok, hanem az épületről alkotott információs adatbázis szerzője és tulajdonosa lesz, így ő kontrollálja azt a 
számtalan - kompromisszumok szülte - módosítást, ami a kivitelezés közben szinte mindig elkerülhetetlen. Ezzel visszaadtuk az építész kezébe azt a befolyást és hatalmat a megvalósuló épület felett, amelyet néhány évszázada a reneszánsz időkben még élvezett, és amit az építészet iparosodása során fokozatosan elveszített. Az építészeti tervezést tehát nem a fárasztó kézi munka automatizálása forradalmasítja (amit a CAD jelentett) hanem az információ hatalma. Ez nem csak az építészeti tervezésre igaz, és azt hiszem, hogy ezzel az informatika mai forradalmának lényegét kezdtük érezni.

\section{NEGYEDIK IPARI FORRADALOM?}

A negyedik ipari forradalom elnevezéssel Klaus Schwab a napjainkban zajló informatikai forradalom jelentőségét érzékeltette. Az elsőt az emberi (és állati) erőt kiváltó gépekkel, a másodikat a tömeggyártással, a harmadikat az automatizálással jellemezte, míg a mai információtechnológia csodáit (például: Internet of Things, Cloud Computing, vezető nélküli gépjármüvek, mesterséges intelligencia, 3D-nyomtatás stb. stb.) ezek szerves folytatásaként értelmezi. Könyve bevezetőjében ezt írja: „,...az új technológiai forradalom nem kevesebbet jelent, mint az emberiség átalakitását. Egy olyan forradalom kezdeténél vagyunk, amely alapvetöen változtatja meg életünket, munkánkat és egymáshoz való viszonyunkat."

Ezzel teljes mértékben egyetérthetünk, de úgy érzem, hogy a napjainkban zajló technológiai forradalom ezen alkotásai - lenyügöző nagyszerüségük ellenére - nem az informatikai forradalom lényegét illusztrálják, és a negyedik ipari forradalom kifejezés nem igazán szerencsés. Félreérti, sőt alábecsüli a napjainkban éppen csak megkezdődött technológiai forradalom igazi jelentőségét. Nehéz lenne vitatni, hogy az ipari forradalom Schwab által meghatározott mérföldkövei nagy hatást gyakoroltak életünkre, de az emberiség történetében volt két olyan forradalmi változás, amelyek sokkal nagyobb mértékben változtatták meg „életünket, munkánkat és egymáshoz való viszonyunkat" - hogy Schwab szavaival éljünk. A napjainkban zajló és ma még beláthatatlan technológiai robbanást ezért szerencsésebb nem a negyedik ipari, hanem inkább a harmadik informatikai forradalomként aposztrofálni. Mindez életünkre, munkánkra, egymáshoz való viszonyainkra, sőt talán az emberi faj egészének további sorsára sokkal nagyobb hatással lehet, mint az ipari forradalmak összes eddigi vívmánya együttvéve volt. A Schwab által teljes joggal gigantikusnak és történelemformálónak tekintett változást nem az ipari forradalmak következő lépéseként, hanem inkább az előző két „,informatikai forradalom” kihívásaira adott válaszként, azok szerves folytatásaként lehet értelmezni. 


\section{AZ ELSŐ INFORMATIKAI FORRADALOM: AZ INFORMÁCIÓ ÁTADÁSA, A BESZÉD}

Mint Jared Diamond is kiemeli (2009), az ember mint az egyik föemlös mintegy másfél millió éven keresztül alig változott, de ha a kb. 40-50 ezer évvel ezelőtt kihalt Neander-völgyi ősember egy feltámasztott és mai ruhába öltöztetett példányával sétálnánk végig a Nagykörúton, azzal igencsak nagy feltünést keltenénk. Viszont, ha a kb. negyvenezer évvel ezelőtt megjelent cro-magnoni ősemberrel, más néven Homo sapiensszel tennénk ugyanezt, gyakorlatilag észrevétlenek maradhatnánk. Melyek voltak a különbségek? Néhány egyéb külső jegy mellett eltért például az állkapocs formája is.

Az antropológusok szerint a Homo sapiensnél alakult ki elöször az az állkapocsforma és a többi kifinomult hangképző szerv, amelyek a tagolt beszéd, tehát a viszonylag bonyolult információ átadására tették képessé az embert.

Természetesen az információcsere változatos formái léteznek az állatvilágban is. Ilyen a párosodásra történő felhívás, a különféle veszélyek jelzése vagy a táplálék felfedezése. Jelenlegi tudásunk szerint azonban nem ismerünk olyan állatfajtát, amely olyan bonyolult információ átadására is képes, mint például, hogyha egy bizonyos fajta követ megfelelően ütögetünk egy másik fajta kőhöz, akkor az így élessé tehető, vágni lehet vele, és ha indákkal egy hosszabb fadarabhoz kötözzük, akkor a fadarab nyélként funkcionálva nagyobb erő kifejtésére teszi képessé a megélesített kődarabot, és az fegyverként vagy szerszámként használható. Primitív kőeszközöket vagy más, szerszámként is használható tárgyakat nemcsak a Homo sapiens, de bizonyos állatfajták is használnak, például a harkálypinty, a dögkeselyü vagy a tengeri vidra is használ „szerszámokat” élelme megszerzéséhez. A modern emberrel anatómiai szempontból gyakorlatilag azonos cro-magnoni azonban sokkal bonyolultabb eszközöket, nyéllel ellátott pattintott kőből készült, különböző célokra specializált szerszámokat, íjakat, nyilakat, hálókat, horgokat készített, sőt, megjelent a müvészet is, barlangrajzok, szobrok, ékszerek és hangszerek formájában.

Mint Harari írja a Sapiensben (2015), a leginkább előremutató változás az volt, hogy míg a korábbi kőkorszaki eszközök több százezer évig gyakorlatilag változatlanok voltak, addig a sapiens eszközei folyamatos fejlödést mutattak. Megjelent az embert az állatvilágból kiemelő legfontosabb tulajdonság, az innováció képessége. Ezt pedig elsősorban a beszéd révén megfogalmazott és átadott összetett információ tette lehetővé.

A beszéd általi kommunikáció azonban nemcsak bonyolult szerszámok és fegyverek alkotására tette képessé a sapienst. A vadászat megszervezése, koordinálása is szükséges volt az embernél sokkal erősebb nagyvadak leterítéséhez. Farkasfalkák is koordinálják a vadászatot, ha nem is annyira szofisztikált munkamegosztással, mint az emberi hordák, de a sapiens hamarosan túllépett a hordák szintjén, és olyan törzsekbe szerveződött, amelyekben már nem ismert mindenki 
mindenkit személyesen. Ehhez pedig az együttélési szabályok fokozatos kialakítására volt szükség, ami ugyancsak elképzelhetetlen lett volna a beszéd jelentette szofisztikált információcsere nélkül. A bonyolult információcserére képes és törzsekbe szerveződött sapiens hamarosan kiszorította (sőt, ismerve hajlamainkat és történelmünket, valószínűleg kiirtotta) a nála egyébként fizikailag sokkal erősebb Neander-völgyi ösembert.

A cro-magnoni és a többi ősember közötti különbség eredetét tehát a beszéd, a viszonylag összetett információ cseréjének képessége jelentette, ezért a Homo sapienst, azaz a „gondolkodó embert” akár Homo informaticusnak is nevezhetnénk.

Az ember hangképzése és az információ átadását szolgáló beszéd fizikailag rendkívül kifinomult és bonyolult árnyalatokkal színezett, és az evolúció során kiemelt szerephez jutott. Esetleg ez lehet a magyarázata annak, hogy míg a képés alakfelismerés számítógépes technikája több évtizede az emberi szemnél sokszorta nagyobb megbízhatósággal müködik, addig a gépi beszédfelismerés nagyon sokáig gyerekcipőben járt, annak ellenére, hogy a hang fizikai megjelenése (levegőhullámok) semmivel se nehezebben elemezhető gépekkel, mint az elektromágneses hullámok által megjelenített kép. Lehetséges, hogy a gépi beszédfelismerés lemaradása a képfelismerés mögött nem abszolút, hanem csak relatív az ember beszéd-, illetve képfelismerő képességéhez képest. Feltételezhető, hogy az evolúció során a beszéd útján átadott információ értelmezése a túlélés szempontjából fontosabbnak bizonyult a képfelismerésnél, ezért agyunk a képitől eltérő és számítógéppel nehezebben szimulálható szinten tanulhatta meg értelmezni a hangban lévő információt (például a beszéd hangulatát). Nem arról van szó, hogy a hallásunk kifinomultabb lenne a látásunknál, hiszen ennek az ellenkezője igaz, a látásközpont idegsejtjeinek száma jóval nagyobb, mint a hallásközponté. De ettől függetlenül esetleg lehetséges, hogy a Homo sapiensnél a hangban rejlö információ értelmezésének képessége fontosabb lett az evolúció során, mint a semmivel nem információszegényebb képek értelmezése. E hipotézis szerint a képfelismerés evolúciós szerepe kezdetben - az állatvilághoz hasonlóan - az embernél is elsősorban a veszélyek és az élelem felismerésében jelentkezett, míg a beszéd útján történő információcsere az evolúcióban sokkal nagyobb szerephez jutó szerszám- és fegyverkészítést, valamint a társadalmi együttműködést tette lehetővé.

Mindezek alapján állítható, hogy az emberi lény fejlődésében az első nagy ugrást és az állatvilágból való kiemelkedését az összetett információ átadásának képessége teremtette meg, ezért a tagolt beszéd megjelenését tekinthetjük az elsö informatikai forradalomnak.

A beszélő Homo sapiens törzseinek volt még egy - az állatvilágtól megkülönböztető - egyedülálló sajátossága: a törzs idősebb tagjainak tisztelete, annak ellenére, hogy ők a fiataloknál nyilván sokkal gyengébbek, és ezért a törzs számára látszólag kevésbé hasznosak voltak. Mit tudhattak ezek az idősek, amit a fiatalok 
nem? Az életük során felhalmozott információ mennyisége volt több, gazdagabb, mint fiatal társaiké. Talán már a törzsi társadalmak is felismerték, hogy a megörzött információ mekkora érték, mekkora hatalom. Ugyanakkor azzal, hogy az információ tárolásának egyetlen médiuma az idősebbek - valljuk be eléggé korlátozott - memóriája volt, már ekkor felmerülhetett egy újabb, második informatikai forradalom igénye.

\section{A MÁSODIK INFORMATIKAI FORRADALOM: AZ INFORMÁCIÓ TÁROLÁSA, AZ ÍRÁS}

Az információcsere képessége nyomán az emberi faj fejlödése felgyorsult, és a második nagy ugrására már nem kellett millió évet várni. A Homo informaticusnak elég volt néhány tízezer év ahhoz, hogy felfedezze az információ tárolásának módját, vagyis az irást.

Az írás, azaz az információ megőrzésének és felhalmozásának képessége, fantasztikus eredményeket hozott. A nemzedékek által felhalmozott és exponenciálisan növekvő tudás újabb és újabb nemzedékek számára vált elérhetővé, időbeli és földrajzi határok nélkül. Ennek következtében a már időszámításunk elött több ezer évvel „írástudó” Közel-Keleten, Kínában, Indiában és Európában születhettek meg a civilizáció első csodálatos alkotásai, míg ott, ahol nem ismerték az írást, Afrikában a Szaharától délre és Ausztráliában sokkal lassabb volt a fejlődés. Az európaiak hódítása előtti Amerikában is csak ott jöhettek létre komolyabb civilizációk - a maja és az inka -, ahol már létezett az írásnak valamilyen formája, bár több ezer éves késéssel az eurázsiai kontinenshez képest. Megcsodáljuk ugyan Peruban a gyönyörü fekvésű Machu Pichut, de alig ötszáz éve is még primitív technikával, boltív és kötőanyag nélkül, csupán egymásra rakott kövekből építkeztek, akkor, amikor Európában már több száz éve magasodtak ég felé a katedrálisok, és Kínában már másfél ezer éve állt több ezer kilométer hosszan a Nagy Fal.

Az információ tárolására képes társadalmakban a törzsközösségekböl birodalmak és civilizációk születtek, a társadalom tagozódott, többnyire mély társadalmi egyenlőtlenségeket, feszültségeket eredményezve. Ugyanakkor a tudomány és a technika fejlődése feltartóztathatatlanná vált. Egyre pusztítóbb fegyverek megalkotására lettünk képesek, és az ebben élenjáró (vagy csak legagresszívebb?) európai civilizáció a hajózás technikájának fejlődésével meghódította az egész földgolyót, és ezzel útjára indította a mára kiteljesedni látszó globalizációt. Az emberi és állati erőt megsokszorozó gépek megalkotása nyomán pedig eljutottunk egészen az ipari forradalomig. Mindezen csodák nem történhettek volna meg az emberi tudás felhalmozását lehetővé tevő írás nélkül.

A második informatikai forradalom fontos állomása volt a nyomtatás feltalálása, ami az információ szinte korlátlan sokszorozását, ezzel árának radikális 
csökkenését eredményezte, és így a mindaddig csak egy szűk elit privilégiumaként létező írást a tömegek számára is elérhetővé tette. A mai informatikai forradalmat a könyvnyomtatás felfedezéséhez is szokták hasonlítani, és gyakran nevezik a „Gutenberg-galaxis” végének is, de ezzel az analógiával ugyanúgy alábecsüljük a mai informatikai forradalom jelentőségét, mint amikor negyedik ipari forradalomként aposztrofáljuk. A könyvnyomtatás az írásbeliség korában csak valami olyasmit jelentett, mint a mai digitális (harmadik informatikai) forradalom idején a személyi számítógépek megjelenése volt a hetvenes évek végén: a digitális forradalom demokratizálódott, megszünt egy szűk elit kiváltsága lenni, elérhetővé vált a tömegek számára is, megsokszorozva így a hatását.

A könyvnyomtatás azonban láthatóvá tette a második informatikai forradalom kihívását is: olyan hatalmas mennyiségű információ képződött, amennyi már gyakorlatilag átláthatatlanná, feldolgozhatatlanná vált. Az ún. „információrobbanás" fogalmát a mai korhoz szokták társítani, pedig ez jóval korábban, még a könyvnyomtatás elterjedését is évszázadokkal megelőzve megtörtént. Kétezer évvel ezelött az Alexandriai könyvtár már közel félmillió kötetet őrzött, és ez a hatalmas információtömeg már akkor is gyakorlatilag feldolgozhatatlan volt. Google kereső hiányában szinte megoldhatatlan feladatot jelentett megtalálni benne, amire szükségünk volt, ezért újra és újra felfedeztük mindazt, amiről később kiderült, hogy már a régi görögök is tudták, sőt le is írták.

\section{A HARMADIK INFORMATIKAI FORRADALOM: A VÉGTELEN INFORMÁCIÓ FELDOLGOZÁSA}

Az írás felfedezése után már alig hatezer évet kellett csak várni arra, hogy a harmadik informatikai forradalomban lehetőség nyíljon az írásbeliség korában felhalmozott hatalmas mennyiségü információ elérésére és feldolgozására.

A számítógépet - ahogyan arra a nevében levő „gép” szócska utal - eredetileg valóban csak egy újfajta gépnek tekintették, ami az ipari forradalom újabb termékeként a számolás fáradságos munkáját automatizálta. A Budapesti Müszaki Egyetemen például a hatvanas-hetvenes években a számítástechnika az Automatizálási Tanszék szakterülete volt. Az első számítógépek megalkotóinak, köztük honfitársunknak, Neumann Jánosnak, valóban csak ennyi volt a célja: nagy mátrixok összeszorzása, a korábbi technikával elvégezhetetlen mennyiségủ számtani müvelet gépesítése. De azt hiszem, Neumann János hasonló helyzetben volt, mint négyszázötven évvel korábban Kolumbusz, aki csak egy új, a korábbinál rövidebb és gyorsabb utat keresett a már addig is ismert Indiába, miközben valami sokkal nagyobb dolgot, egy új világot fedezett fel. Neumann sem csupán a számolás módját gépesítette, hanem valójában ő is egy új világ felfedezőjévé, a harmadik informatikai forradalom elindítójává vált. 
Neumann és társai számára a számítógép processzorának legfontosabb funkciói még a számtani alapműveletek voltak. A processzor azonban képes egy ezeknél egyszerübb, ugyanakkor sokkal messzebbre mutató, s vélhetően az emberiség jövőjét teljesen átalakító funkcióra is. Ez pedig a „compare”, azaz az összehasonlítás, tehát az a funkció, amely megállapítja, hogy két (nullát vagy egyet ábrázoló) bit egymással azonos-e vagy sem. Ez a funkció ugyanis az alapja a keresésnek, tehát a hatalmas mennyiségü, digitálisan tárolt információtömegben bizonyos minták beazonosításának. Ezzel pedig a számítógép, vagy eredeti angol nevén computer (sokkal találóbb francia nevén ordinateur, azaz rendezö) választ ad a második informatikai forradalom kihívására: képessé tesz a digitálisan tárolt és gyakorlatilag végtelenné váló információtömeg elérésére, értelmezésére, rendezésére, a benne való keresésre, egyszóval az információ feldolgozására. Ezt a technológiát a szakma ma már ICT, azaz infokommunikációs technológia gyüjtőnéven jegyzi, jelezvén, hogy a számítógépnek más „gépeknél” sokkal közelebbi rokona a telefon, annyira, hogy az ma már össze is olvadt a számítógéppel.

Ezért félreértés a számítógépet az emberi munkát felgyorsító vagy automatizáló gépek sorába illeszteni. Egy egyszerủ példával megvilágítva: amikor egy vállalat pénzügyeit számítógépre visszük, akkor az igazi haszon nem abban jelentkezik, hogy gyorsabb, netán olcsóbb lesz a könyvelés. Többnyire nem lesz olcsóbb, de a digitálisan tárolt pénzügyi adatok sokféleképpen rendezhetők, sokféle szempont szerint lekérdezhetők. Ezáltal sokféle lehetséges következmény modellezhetö, és így a vállalat menedzsmentje az információ birtokában sokkal jobb üzleti döntéseket tud hozni. Hasonlóan a fentebb említett építészeti tervezőprogramunkhoz, amely nem elsősorban a rajzolás automatizálásával a rajzolók bérét célozza megtakarítani, hanem az építész kezébe ad nagyobb kontrollt, hatalmat a megvalósuló épület felett.

Visszatérve Klaus Schwab könyvéhez, egyet kell értenünk azzal, hogy a 3D-nyomtatás, a robotok vagy a vezető nélküli autók és az informatika eddigi eredményeinek összes többi általa felhozott példája radikális változásokat fog hozni életünkben. Könyve bőséges példákkal szolgál a várható, illetve már ma is tapasztalható változásokra a munkaerőpiacon, a társadalmi struktúrákban és életünk ezer más dimenziójában. Csak abban vitatkozunk Schwabbal, hogy az informatika forradalmának életünkre, munkánkra és egymással való kapcsolatainkra gyakorolt hatása az ipari forradalmak eredményeivel állítható-e legjobban párhuzamba. Úgy érezzük, hogy az informatika eszközeinek használatából eredő legnagyobb haszon (és veszély) nem az emberi munka gépesítése, hanem sokkal inkább az információ hatalma. A mai ICT-forradalom sokkal inkább a beszéd, mint a gőzgép felfedezésének szerves folytatása, és életünket, fajunk jövőjét a Google kereső sokkal inkább befolyásolja, mint a Google Car.

Arról, hogy mindez hová vezet, egyelöre nagyon keveset sejthetünk. Kezdetben valószínúleg a már beszélő cro-magnoni ősember sem látta elöre, hogy kommu- 
nikációs képessége milyen ügyes szerszámok és fegyverek készítéséhez, a hordáknál sokkal fejlettebb törzsközösségek létrejöttéhez vezet majd, mint ahogy a sumerek sem sejthették, hogy az írásban megőrzött és a következő nemzedékekre hagyományozott és felhalmozott információ és tudás az Akropolisz felépítéséhez, majd az ipari forradalomhoz vezet.

\section{A HARMADIK INFORMATIKAI FORRADALOM LEHETŐSÉGEI ÉS VESZÉLYEI}

Néhány dolgot azonban már ma is tudhatunk. Látjuk például, hogy a digitális információ fénysebességgel történő korlátlan és szinte ingyenes továbbítása hogyan változtatja meg és teszi lehetővé a nagyvállalatok globális müködését. És ma már nemcsak nagyvállalatok müködnek globálisan. Egy nemrég alakult „magyar” start-up cég négy munkatársa például (a négy alapító) a világ négy sarkában, Budapesten, Palo Altóban, Fokvárosban és Frankfurtban dolgozik és él, első piacuknak pedig speciális adottságai miatt Fokvárost választották. Az informatika mai forradalma - sok egyéb ma még beláthatatlan hatása mellett - kiteljesíteni és végképp visszafordíthatatlanná látszik tenni a nagy felfedezésekkel mintegy ötszáz éve elindult globalizációt. Mostanában kezdjük sejteni azt is, hogy ennek milyen - az eddigi társadalmi szerkezetekben szinte kezelhetetlen - következményei lesznek. Az üzleti világ globális müködését nehéz, csaknem lehetetlen nemzeti keretek között szabályozni, lásd az Über vagy akár a Google, a Facebook és az Apple konfliktusait különböző nemzeti adóhivatalokkal. A globalizáció ellen lehet küzdeni, de ennek körülbelül annyi értelme van, mint küzdeni az időjárás ellen. Emellett szembenézünk egy sor olyan válságjelenséggel is (globális felmelegedés, tömeges migráció stb.), melyekre ugyancsak nehéz nemzeti keretek között választ találni. Azt is látjuk már, hogy a korábban elképzelhetetlen mértékben felgyorsult információcsere polarizálódása (lásd például Facebook), de még inkább a határokon átnyúló manipulálhatósága, történelmünk eddigi legsikeresebb társadalmi berendezkedésének, a képviseleti demokráciának az alapjait kezdi aláásni. Egyre valószínűbb, hogy tartós, az informatika korának megfelelő megoldás csak valamiféle globális kormányzás mellett lenne elképzelhető. De ilyen mértékü hatalmi átrendeződés sajnos a történelemben ritkán szokott eröszak nélkül megvalósulni.

Pár évtizeddel ezelőtt még az ipari forradalom legveszélyesebb termékétől, az elszabaduló és felelőtlen kezekbe kerülő atomenergiától tartottunk legjobban. Egyelőre úgy tünik, ezen a veszélyen talán képes úrrá lenni az emberiség, de a harmadik informatikai forradalom olyan területeken is hozott már eredményeket, ahol talán még nem is sejtjük, milyen új veszélyek leselkednek ránk.

Csak egyetlen példa a sok közül: Az emberi DNS-molekula bizonyos biológiai funkcióinak dekódolását az informatika egyik legnagyszerübb alkalmazásának 
és az orvostudomány legígéretesebb diadalának éljük meg. De ha a DNS-ben tervezett célzott módosítások (genetic engineering) ma még gyógyíthatatlan betegségek legyőzésének vagy az öregedés lassításának ígéretével kecsegtetnek, akkor nehéz lesz nem átlépni a kényes határt az orvoslás és a Teremtés között. Persze a magunknál is intelligensebb lények létrehozása és felettük a kontrol elvesztése inkább a bulvárlapok témakategóriájába tartozik, és a molekuláris genetika kapcsán sokkal több pozitív (ráadásul viszonylag rövid távon is reális) alkalmazásról lehetne beszélni, de a valós veszélyeket sem szabad lebecsülni. Harari hivatkozott könyve, a Sapiens (eredeti angol címén From Animals into Gods) ijesztő példákat idéz a már ma is zajló genetikai kísérletekről. A Jurassic Park szerzőinek fantáziáját megszégyenítő génsebészeti beavatkozásokról, őslények reprodukálásáról olvashatunk, sőt a Neander-völgyi ősember maradványaiból kivont DNS-molekulák emberi embrióba oltására is terveztek már tudományos célú projekteket.

A természet (vagy az Isten, kinek-kinek világnézete szerint) legcsodálatosabb alkotásának, magának az evolúciónak a reprodukálása talán még ennél is ijesztőbb: olyan számítógépes vírusokat is alkottak már, amelyek véletlen hibákat generálva másolják magukat sokmillió példányban, és így a világhálón csak a környezethez (más vírusok, vírusirtók stb.) jól alkalmazkodó változatok szaporodnak tovább. Az ilyen, ember alkotta evolúció esetleg valamikor csak annyiban fog különbözni a természetestől, hogy sok-sok milliárdszorosan gyorsabb lehet.

A fajunk sorsáért érzett aggodalom nem új. Madách Imre költői zsenialitása már százötven éve megfogalmazta ugyanezt a problémát az Ember Tragédiájában, amikor Lucifer a Teremtésre oly büszke Urat figyelmezteti:

\author{
„Az ember ezt, ha egykor ellesi, \\ Vegykonyhájában szintén megteszi. - \\ Te nagy konyhádba helyzéd embered, \\ S elnézed néki, hogy kontárkodik, \\ Kotyvaszt s magát Istennek képzeli. \\ De hogyha elfecsérli s rontja majd \\ A föztet, akkor gyúlsz késö haragra. \\ Pedig mit vársz mást egy mükedvelőtől?"
}

IRODALOM

Diamond, J. (2009): A harmadik csimpánz felemelkedése és bukása. (ford. Györvári B.) Budapest: Typotex Kiadó

Harari, Y. N. (2015): Sapiens. (ford. Torma P.) Budapest: Animus Kiadó

Schwab, K. (2016): The Fourth Industrial Revolution. Penguin Random House UK 